Canadian University Music Review

Canadian University Music Review

Revue de musique des universités canadiennes

Linda Hutcheon and Michael Hutcheon. Opera: Desire, Disease, Death. Texts and Contexts, vol. 17. Lincoln: University of

Nebraska Press, 1996. xvi, 294 pp. ISBN 0-8032-2367-6 (hardcover)

\title{
Rebecca Green
}

Volume 18, numéro 2, 1998

URI : https://id.erudit.org/iderudit/1014661ar

DOI : https://doi.org/10.7202/1014661ar

Aller au sommaire du numéro

\section{Éditeur(s)}

Canadian University Music Society / Société de musique des universités canadiennes

\section{ISSN}

0710-0353 (imprimé)

2291-2436 (numérique)

Découvrir la revue

Citer ce compte rendu

Green, R. (1998). Compte rendu de [Linda Hutcheon and Michael Hutcheon. Opera: Desire, Disease, Death. Texts and Contexts, vol. 17. Lincoln: University of Nebraska Press, 1996. xvi, 294 pp. ISBN 0-8032-2367-6 (hardcover)]. Canadian University Music Review / Revue de musique des universités canadiennes, 18(2), 106-110. https://doi.org/10.7202/1014661ar

All Rights Reserved (C Canadian University Music Society / Société de musique des universités canadiennes, 1998
Ce document est protégé par la loi sur le droit d'auteur. L’utilisation des services d'Érudit (y compris la reproduction) est assujettie à sa politique d'utilisation que vous pouvez consulter en ligne.

https://apropos.erudit.org/fr/usagers/politique-dutilisation/ 
Linda Hutcheon and Michael Hutcheon. Opera: Desire, Disease, Death. Texts and Contexts, vol. 17. Lincoln: University of Nebraska Press, 1996. xvi, 294 pp. ISBN 0-8032-2367-6 (hardcover).

Love and death have long been symptomatic of the operatic condition; a new diagnosis implicates them, with disease, in a pathological triangle. In Opera: Desire, Disease, Death, Linda and Michael Hutcheon draw on a stunning array of sources to reconstruct how particular diseases were represented in operas from the nineteenth and twentieth centuries. ${ }^{1}$ Their project "offers a way to look at the historically different ways people have constructed notions of themselves and their societies, in part through the prevailing concepts of love and death, but also through those of disease and health-social as well as individual" (p. 14). In the process, we are given a unique perspective on opera that looks at Wagner's sources with the clinical details of syphilis in mind and listens to Violetta's cough as well as her cabalettas.

Like a number of recent books on opera, this one was inspired by the spectator's passion for opera and followed up by scholarly curiosity. ${ }^{2}$ In this book, two opera fans, who also happen to be a literary theorist and a physician, make sense of their experiences in the opera house. In the prologue, they analyse their "Collaborative Research, or Marital Methodologies" ("he 'obsesses' and she 'compulses"' [p. xiv]) to explain how their particular disciplinary habits suggested this unusual approach to opera. ${ }^{3}$

This book (part detective story, part Texaco opera quiz, part close reading) brings together readers who do not necessarily attend the same parties: musicologists, medical historians, opera fans. The text is relatively jargon-free, so those unfamiliar with recent developments in literary theory and cultural studies will not be discouraged. The book grew out of a series of lectures to students at the University of Toronto and it retains an informal quality that makes it readily accessible, if overly conversational at times (e.g., "We are in Paris ..." [p. 41]). Often the writing is playful and clever, but it can also be awkward and repetitive, perhaps a residue of its spoken origins. In general, the breadth of research and ambitious scope of this book deserved an editor more scrupulous than the one who missed errors like Die Freischütz.

The question of translation is always difficult in books on opera, which usually involve a number of languages. A variety of strategies is employed here: sometimes the text is translated, but more often it is paraphrased. This is an interesting solution which is considerate of the general reader without

1 Although the book is weighted towards discussion of its nineteenth-century repertoire, about two thirds of the operas discussed are from the twentieth century, most of them from the latter half.

2For example, see Catherine Clément, Opera, or The Undoing of Women, trans. Betsy Wing, foreword by Susan McClary (Minneapolis: University of Minnesota Press, 1988); Wayne Koestenbaum, The Queen's Throat: Opera, Homosexuality, and the Mystery of Desire (New York: Poseidon Press, 1993); Susan J. Leonardi and Rebecca A. Pope, The Diva's Mouth: Body, Voice, Prima Donna Politics (New Brunswick, N.J.: Rutgers University Press, 1996); Sam Abel, Opera in the Flesh: Sexuality in Operatic Performance (Boulder, Colo.: Westview Press, 1996).

3For an alternative approach to the operatic repertoire co-authored by a lesbian couple, see Leonardi and Pope. 
short-changing the polymath. There are places, however, where the original text does not appear, which is frustrating for anyone who might wish to follow the argument back to its source.

As a refreshing consequence of their spectatorly viewpoints, the Hutcheons approach opera in terms of the performance rather than the score or the libretto, considering visual and musical as well as literal aspects of the operatic work, although not necessarily altogether. ${ }^{4}$ This performance-oriented approach is very effective, for example, in a discussion of Wagner's prose that takes into account how the text is actually heard. This said, the authors are fundamentally readers, and their discussion gravitates towards the textuality of the libretto and plot details. There is no privilege extended to the music of these operas, but unlike many libretto-based studies of opera, this book does not ignore musical points of view either. On the contrary, the Hutcheons have read the musicological literature and frequently cite it to support their arguments. One could quibble about awkward references to "the C major" (p. 109) or a misleading association of polyphony with harmony (p. 88), but it is encouraging to see scholars from other fields make the effort to incorporate musical knowledge into their work.

The emphasis on performance is stressed in chapter 1 ("Melodies and Maladies"), in which the authors remind us of the theatricality of opera and its ability to incarnate: "the body, the singing body, gives voice to the drama of the suffering person" (p. 12). Asking "Why Disease and Opera?" the Hutcheons promise to explore illness as well as death (which has received most of the attention), drawing on cultural critics such as Susan Sontag and Sander Gilman to theorize social constructions of diseases. The authors argue that "the act of paying critical attention to these diseases can bring into focus different aspects of the narrative and the text-and even the music" (p. 18). Indeed, their research suggests why the theme of cold in La bohème would have sent a chill down the spine of a Parisian opera-goer of the 1890s, finds significance in the beauty marks in Hogarth's The Rake's Progress, and can account for Violetta's final burst of vocal energy in La traviata as an instance of medical realism rather than operatic indulgence.

The authors are careful to include reception history as part of the operatic "text," taking opera critics from Nietzsche to Arnold Whittall to Susan McClary as their point of departure. This is reasonable enough, given the difficulties of retrieving audience responses; however, it results in a certain gap between the carefully reconstructed medical-cultural context of a particular moment and the history of a work's reception over time. Ultimately, the Hutcheons are not concerned with how historical audiences viewed these works, but with how we perceive them based on a past of which we are only partially aware, a point to which I will return.

4Considering that the Hutcheons are based in Toronto, and that most of the illustrations are taken from the Canadian Opera Company, it is likely recent productions by this company which they have in mind. 
The book is arranged chronologically, with each chapter devoted to a particular disease and the operas which feature it. In chapter 2 ("Famous Last Breaths: The Tubercular Heroine"), the Hutcheons begin with tuberculosis, observing that "as a disease that affects the lungs, and thus involves (literally and metaphorically) both inspiration and expiration, it is also perhaps the archetypal operatic disease" (p. 21). Although both La traviata and La bohème feature a soprano dying of the disease, they were written on either side of the discovery, in 1882, that tuberculosis was infectious. As a result, desire and disease are implicated very differently in the two operas. Whereas the symptoms of Violetta's affliction (flushed complexion and shining eyes) contribute to her sexuality, Mimi's symptoms (shivering cold and paleness) point to the dangerous social conditions which helped spread tuberculosis. In this context, Rodolfo's longing for Mimi becomes infused with danger, an observation that will surely invite directors to reconsider their interpretations of this opera.

Syphilis, the disease treated in both chapters 3 and 4, offers a model of the process by which sexuality and disease have been linked in the discourse on plagues, a central argument of this book. In chapter 3 ("Syphilis, Suffering, and the Social Order: Richard Wagner's Parsifal), the Hutcheons make the case that Amfortas suffers from syphilis. This allows them to place the Christian aspects of this opera into a wider discourse on sexuality and suffering in nineteenth-century culture, and to argue that Amfortas's psychological suffering is closely linked with his physical suffering as a victim of the "scourge of God." The history of syphilis, in which the blame fell on soldiers and prostitutes for spreading the disease, offers a new way of seeing the Flower Maidens and the Grail Knights. At the centre of this tale, and this chapter, lurks Kundry, a symbol of the racial and sexual Other. The final section, a fascinating analysis of the musicality of Wagner's prose, teases out the ways Wagner embedded his themes of sexuality and spirituality even at the level of the word. Much of the historical context for this reading of Parsifal is provided in chapter 4 ("The Pox Revisited: The 'Pale Spirochete' in Twentieth-Century Opera"). In our century, the pox finally came under medical control. The Hutcheons draw on discourses of public health to explain how the disease could shift in a matter of decades from a threat of horror (in Lulu) to an object of ridicule (in Candide).

In chapter 5 (“'Acoustic Contagion': Sexuality, Surveillance, and Epidemics"), the Hutcheons address the chronic unease over the disease of cholera. The notion that unhealthy or miasmic atmospheres could facilitate epidemics spread into the domain of moral and social health so that cholera came to be associated with a "secret vice" (p. 123). The surveillance and policing justified by attempts to limit outbreaks of cholera in the nineteenth century allowed the bourgeoisie (i.e., opera audiences) into intimate spaces where they could observe the sexual practices of (mostly) lower classes and label them abnormal. When cholera appeared on the operatic stage (but not until the next century), it was linked to same-sex desire symbolic of sexual ill-health: Countess Geschwitz's communicates both affection and infection to Lulu; Aschenbach's illicit passion for Tadzio in Death in Venice grows in tandem with a cholera 
epidemic; and Mario kisses the Magician in a miasmic environment of physical and political ill-health. This chapter reveals as much about the operatic treatment of homosexuality as cholera, illustrating the pathologization of sexuality whereby "homoerotic desire is marked in terms of disease" (p. 146). What is perhaps most astonishing (and disturbing) is that these operas all received their premieres within the last twenty-five years.

The chapter ends with the observation that "if there ever was an art form whose power could be described in terms of 'acoustic contagion,' it is opera" (p. 160). In a fascinating passage, the authors demonstrate an instance of this. In Mario and the Magician, by Harry Somers and Rod Anderson, based on the story by Thomas Mann, both Cipolla, the magician, and Somers, the composer, draw on their powers of rhetoric to "infect" their audiences.

At this point [where Cipolla is first mentioned] Somers inserts quite recognizably diatonic, melodic music into a basically atonal score in order to represent (and elicit) patriotic mass emotion (in the stage listeners). However, the theater audience's manifest delight in hearing comfortably tonal music for almost the first time in the opera cannot help implicating it in subtle and historically interesting ways. What does it mean that "Giovinezza, giovinezza"-a fascist song-is the only tune being whistled on the way out of the theater? (p. 153)

This provocative question raises a number of issues which are not pursued, but it does induce a kind of chronological vertigo for the reader, especially one who was part of that audience. For much of the book, the Hutcheons can refer to a historical audience comfortably remote from the reader; eventually, however, past and present begin to merge. On p. 176, the Hutcheons refer to an association between sex and smoking in "our culture" which appears to include audiences of Italian opera from ninety years ago! At what point does an audience lose touch with the cultural matrix in which a work was created?

In the case of Mario and the Magician, which was first performed in 1992, the operatic audience clearly overlaps with that of the book, implicating the reader who might well be part of that audience. The audience of Mario and the Magician is also the audience (an audience) of La traviata, La bohème and Parsifal, which underlines the Hutcheons' argument that opera continues to play a role in shaping notions of illness and disease. Pursuing the argument of the book, one might ask how Mario and the Magician resonated with notions of infectious disease in early 1990s Toronto, especially given the associations of homosexuality and disease in these cholera operas which are not so easy to shelve under "History."

While the strategy of gradually bringing the reader from the past to the present (culminating in a discussion of AIDS) is rhetorically effective, there are some structural problems that result, at least for a reader of historical habits. The book begins with tuberculosis even though syphilis has a much longer medical history and encapsulates many of the issues that are fundamental to the Hutcheons' larger argument. But La traviata (chap. 2) precedes Parsifal (chap. 3) which precedes Lulu (chap. 4), so it would seem that the operatic 
premiere takes precedence. This logic begins to collapse in chapter 4 , where the historical placement of Lulu poses a special problem. Who is the "audience" for this work? Berg's contemporaries of the 1930s? Or those who attended the premiere of the three-act version in Paris in 1979? Given the emphasis placed on production in this book, we might safely assume the latter. But the cholera operas discussed in chapter 5 span the years 1973-92 whereas in chapter 6 (on smoking) we are taken back nearly a century to the period between 1875 and 1918.

This apparent regression is due to the gap between the heyday of smoking as a social habit and its association with lung diseases, which did not gather force until the 1950s and 1960s. In chapter 6 ("Where There's Smoke, There's ..."), the Hutcheons draw attention to the "doubled discourse" that has always circulated around smoking, allowing it to represent both illness and health, male bonding and the dangerous loner, sexual pleasure and danger. Its meaning as represented in operas such as Il tabarro and Il segreto di Susanna helps to explain our own ambivalence towards this habit. The configuration of sexual pleasure and danger in the cigarette offers an occasion for another consideration of the transgressive figure of Carmen. The most illuminating aspect of this discussion, however, is the emphasis on the orientalizing process by which an alluring yet menacing image of Mediterranean femininity in the Spanish/Gypsy/Jewish figure of Carmen is constructed for a French middle-class audience.

Given the historical trajectory of the book and its emphasis on plagues, it seems inevitable to end with a discussion of AIDS. Unfortunately, there has yet to be an opera treating this disease, so, in a rather bold move, opera does not figure at all in the epilogue ("'Life-and-Death Passions': AIDS and the Stage"), at least in the form of any particular work. While offering speculation about what an opera on AIDS would/will look like, the Hutcheons discuss several plays and musicals on the subject showing how these works, often created by people suffering from the disease themselves, countermythologize traditional notions of plagues and their causes. Could it be that opera is immune to AIDS because its generic conditions resist devices like sarcasm and irony, elements upon which the plays and musicals rely? In any case, many of the same images and issues discussed in previous chapters recur in stage works on AIDS, suggesting that one cannot fully understand this repertoire without a knowledge of the history of opera.

By the end of the book, opera seems to get submerged in the larger social issue of how AIDS has been constructed, how meanings have sprung up around it. This has the effect of both displacing opera, and loading it with much heavier cultural freight than it is usually entrusted with. Although this book offers some interesting insights into operatic texts, it is even more valuable as a work of cultural history that demonstrates how thoroughly opera has permeated cultural life. By focussing on opera as it is experienced, the Hutcheons have taken the pulse of opera as a living art form, suggesting that it is by no means a terminal case. 